Izaak Walton League purchased Jackson Hole as an elk sanctuary in 1925, but later the Elk Commission was organised to save the species. More recently, the U.S. Biological Survey, Park Service and Forest Service have studied the Yellowstone herds for food habits, migrations, disease and natural enemies, and in order to obtain more accurate data of the autumn and winter migrations, 150 young elk were captured and marked.

In North America, the range of the elk appears to have extended originally from about the 43rd to the 70 th parallel of latitude (Lydekker), having been reported so far south as Ohio and so far north as the Mackenzie River.

\section{Rabbits and Heather}

While rabbits prefer grass to heather (Calluna vulgaris) as food, the search for food where the rabbit population is large, or persistent harrying on lower ground, frequently induces migration to the edges of the moor. As a result, there is generally a noticeable degeneration of Calluna-heath along the moor-edge and grass-heath eventually takes its place. With new burrows and increase of population in the zone of attack, the degenerating edge tends to move backwards with increasing rapidity.

The formation of established rabbit paths between the Calluna bushes, and the eating down of these to a characteristic low rounded form, is the first step. "The result of this attack is that the once closed Calluna association becomes more open in character, and various grasses (chiefly Agrostis vulgaris and Festuca ovina) - the forerunners of the grass-heath association-appear in the rabbit tracks along with various other plants. At the same time Cladonia coccifera, C. cervicornis, ete., Leucobryum glaucum, Hypnum schreberi, Dicranum scoparium, etc., which previously formed a subordinate layer of vegetation under and around the once luxuriant Calluna bushes, take on a new and enlarged lease of life" (Farrow, J. Ecol., 4, 1916). Wet weather during autumn and winter favours the smothering of the reduced heather bushes by Cladonia spp., under which decay begins. Any fresh young Calluna stems are nibbled off by the rabbits and ultimately the heather is killed. Disintegration follows, and finally the remains of the heather plants, together with the associated Cladonia, become dispersed and a short close turf is formed with a richer flora than previously existed.

\section{Societies and Academies}

\section{LONDON}

Royal Society, November 16. J. W. Cook, E. C. Dopos, C. L. Hewetr and W. Lawson: The œstrogenic activity of some condensed-ring compounds in relation to their other biological activities. In all experiments $100 \mathrm{mgm}$. of substance was administered to ovariectomised rats, and the doses were afterwards decreased if positive results were obtained. Certain di-alkyl derivatives of $1: 2: 5: 6$ dibenz- 9 : 10-dihydroanthraquinol, 1-keto-1 : $2: 3: 4$ tetrahydrophenanthrene, neo-ergosterol, calciferol, ergosterol, 5 : 6-cyclopenteno-I : 2-benzanthracene, $1: 2$-benzpyrene and $1: 9$-dimethylphenanthrene were found to be active. Two interesting features of the results are $(a)$ the remarkable fact that the ostrus phenomena may be produced by compounds which differ relatively widely in molecular structure from the natural product, and $(b)$ that it is possible to have apparently unconnected biological activities associated with the same molecular structure, for two of the substances now shown to be œstrogenic have powerful cancer-producing activity, and another one is the antirachitic vitamin, calciferol. Some degree of unsaturation seems necessary for ostrus. producing activity, as was shown by an examination of several compounds related to the sterols, some saturated, some ethylenic, and some aromatic in type. J. W. Cook, E. C. Dopns and A. Greenwood : Sex change in the plumage of brown Leghorn capons following the injection of certain synthetic cestrus. producing compounds. Intramuscular injection of 1-keto, $1: 2: 3: 4$-tetrahydrophenanthrene, and 9: 10-dihydroxy-9 : 10-di-n-butyl-9 : 10 dihydro-1 : 2 : $5: 6$-dibenzanthracene was followed by a definite appearance of isolated patches of red pigment on the feathers. Later this developed into a definite band across the feather, producing unmistakable demonstration of change from male to female characteristics, as is seen after administration of cestrin. W. E. le G. Clark and G. G. Penman : The piojection of the retina in the lateral geniculate body. The localisation of the retina in the lateral geniculate body of monkeys has been studied by reference to the cellular atrophy which occurs in the nucleus after retinal lesions. Atrophy in the geniculate body is always found to be quite localised and sharply defined after small peripheral lesions. The termination of crossed and uncrossed optic fibres in different cell laminæ is confirmed. The macular area of the geniculate body is more restricted than previous observations have suggested, and is represented by a median sector which is definitely limited to the caudal two-thirds of the nucleus. It involves all the cell laminæ. Fibres from the nasal half of the macula undergo complete decussation in the chiasma, while those from the temporal half remain unerossed. The whole width of the cell lamina in the rostral third of the nucleus is concerned with peripheral vision.

\section{PARIS}

Academy of Sciences, October 9 (C.R., 197, 721-800). Ch. Maurain and C. E. Brazier : The earthquake of October 3, 1933. This earthquake was felt in Paris, the origin being about 120 kilometres away. $\mathrm{C}$. CAMichel, L. Escande, and P. Dupin : Remarks on certain phenomena of lateral contractions in barrages. Lucien Daniel. The curious variations of the descendants of Helianthus Dangeardi to the sixth generation. S. IYANAGA : A lemma of elementary arithmetic in the demonstration of the general law of reciprocity. P.J. MYrkeRG : A new representation of automorph functions. B. HostrnskY : A functional equation which occurs in the theory of linear partial differential equations of the hyperbolic type. A. D. Michal and A. H. Clifford: Analytical functions which are implicit in abstract vectorial spaces. J. SCHREIER and S. ULAM : The group of permutations of the series of natural numbers. $\mathrm{V}$. VÁLCOVICI : The equilibrium of a solid supported on an elastic surface. A. GAX : The plane movement of the incompressible perfect fluid. JACQUES VALENSI : The measurement of the instantaneous velocities above a helix. P. JoLIver : An auto-exciting electrostatic generator. G. Grenet : The theory of ferromagnetic powders and the magnetic susceptibility of 
rocks. G. Fö̈x : The susceptibility of paramagnetic solutions. Experimental evidence in support of the view of the author and also of Fahlenbrach, according to which the law of Weiss is rigorous and the moment, independent of the temperature, can be calculated starting from the Curie constant. ANDRÉ LÉAuté : The ageing of road coatings with a tar base. Study of the effects of various fillers : finely powdered coal with about 33 per cent of volatile matter proved to be the best filler. J. E. Verschaffelt : The law of displacement of chemical equilibrium. W. GrafF : The thermal analysis of the system hydrochloric acid, boron trichloride. Thermal analyses of mixtures of boron trichloride and hydrochloric acid do not indicate the existence of any compound. MLLE. SUzanne VeIL: Discontinuous diffusions in gelatine. HenRI Muraour: The causes of the progressive disappearance of diphenylamine in colloidal powders (explosives). G. Schuster : Contribution to the detection of adulterations of coco-butter. The determination of the index of azelaic acidity. FR. HAHN : A very sensitive reaction for boric acid studied in reference to a biochemical problem. The most sensitive reaction examined was formation of the boric acid complex acid with mannitol, using bromothymol blue as indicator. The method was applied to the examination of a fluid secreted by the pistil of a flower containing a trace of boric acid, the presence of the latter being necessary for the germination of the pollen grain. A. Perrete and R. Perrot : The catalysis and transformation of the alkaline earth cyanides into cyanamides. Study of the effect of the nature of the catalyst on the reaction $\mathrm{CaCl}_{2}+2 \mathrm{NaCN}=\mathrm{CaN}(\mathrm{CN})+\mathrm{C}+2 \mathrm{NaCl}$. Iron, cobalt and nickel are the most active catalysts, platinum and manganese rather less active, whilst twelve other elements were devoid of catalytic activity. JACQUES Maroger and Georges Mourier-Malouf : New remarks on the reconstitution of the paint technique of Jean van Eyck. R. RAmbaud: Study of the $\alpha$-chloro-vinylacetic compounds. J. HocH : General method for the preparation of the di- and triarylacetonitriles, $(\mathrm{Ar})\left(\mathrm{Ar} \mathbf{r}^{\prime}\right) . \mathrm{CH} . \mathrm{CN}$ and $(\mathrm{Ar})\left(\mathrm{Ar}^{\prime}\right)\left(\mathrm{Ar}^{\prime \prime}\right)$ C.CN. Georges Lévy: The preparation of a new ethylnaphthol. This naphthol is the first known naphthol derived from $\alpha$-ethylnaphthalene. J. ORCEL and MuLE. S. CAILLERE : The differential thermal analysis of the montmorillonite clays (bentonites). This method can detect three per cent of kaolinite in montmorillonite clay. F. VLÈS and MLLE. M. GEX : A physicochemical reaction changing after electrical connexion with the earth. A. DauvrluIER: The continuous photo-electric recording of the aurora polaris. The apparatus described shows clearly the daily variation and allows an exact comparison of the auroral and magnetic curves. Lours BEsson: The influence of the smoke of Paris on the transparency of the air on the outer border and suburbs of the city. An analysis of daily observations of the visibility, taken between November and February for the five years 1928-32. Paul BecQuerel: The growth of mosses in an atmosphere of their own making. Five species of moss were placed in a nutritive solution and the tubes evacuated and sealed. The mosses grew under these conditions, giving off oxygen and nitrogen. P. Martens : The origin and function of the superficial folds on the epidermis of flower petals. Georges Truffaut and M. Lefouin : The influence of the microflora of the soil on the growth of wheat. Auguste Chevalier : Adanson, mutationist and evolutionist. J. Costanrin :
Critical remarks on the preceding communication. Georges Bourguignon: The interpretation of the sensibility to heat and pain with the aid of normal sensitive cutaneous chronaxy and their variations in syringomyely. Henrt Vignes and Max Lévy : The acid-base equilibrium and pregnancy. J. BASSET, M. Machebeuf, and G. SANDor : The study of the biological effects of ultra-pressures. The action of very high pressures on proteins. C. Levaditr, G. Hornus, A. Vaisman, and R. Schoen : The presence of the syphilitic virus in the ovary of mice syphilised subcutaneously.

\section{Wasmington, D.C.}

National Academy of Sciences (Proc., 19, 759-801, Aug. 15). J. O. Halford and Leigh C. Anderson: The photochemical production of triphenylmethyl. Triphenylbromomethane in solution in cyclohexane exposed to light from the near ultra-violet and in contact with air or oxygen gives, after several hours' exposure, triphenylmethyl peroxide. The first action is probably photochemical, giving free triphenylmethyl, which reacts with oxygen to give the peroxide. Chester STOck: An amynodont skull from the Sespe deposits, California. EDwin B. WILSON : On the invariance of general intelligence. A mathematical discussion of conditions under which Spearman's $g$ remains invariant. MARGARET FLOY WASHBURN : Retinal rivalry as a neglected factor in stereoscopic vision. A stereoscope slide coloured red on one half and blue on the other appears purple for part of the time, red for part of the time and blue for part of the time. On looking at the far edge of the illuminated whitened side of a cube standing edgeways in a dark room, the side appears to be thrust out and drawn back alternately. These and other experiments suggest that, when the visual fields of the right and left eye are equal in attention value, the stereoscopic effect is due to automatic alternation of the retinal fields. H. E. FARNSworTH and B. A. Rose : Contact potential differences between different faces of copper single crystals. The (111) face is positive with respect to the (100) after outgassing at a high temperature. The potential difference is increased by outgassing, and decreased by evaporation, which causes etching. The observations point to an intrinsic potential difference between the uncontaminated crystal faces. Hence a polycrystalline surface would give only an average contact potential difference. G. A. MrLLER : Number of operators of prime power orders contained in a group. C. B. DAvEnPoRT : Evidences of man's ancestral history in the later development of the child. The proportions of the child's body and limbs differ considerably from those of the adult. Crosssection of chest, upper and lower segments of legs and length of foot in the pre-adolescent stage correspond with those of adult lower forms ; development of the latter has stopped, whereas in man it goes on, until in the adult his position as a nonaboreal biped is established. HARRY H. LAUGHLIN : The general formula of heredity. The formula developed is $K=f(M, R)$, where $K$ is the probability that the pre-indicated or random-selected offspring with a given $M$ or prediction basis will fall within the selected $R$ or class-range of offspring. It is represented by a space-surface called a 'manerkon' and generally takes the form of a skew-saddle. The data used have been obtained largely from thorough bred horses. 